\title{
Studies on chemical elements and anti-nutrients compositions of three traditional vegetable oils in Nigeria
}

\author{
Uche I. Ibanga ${ }^{1^{*}}$, Janet O. Fakunle ${ }^{1}$, Akeem Olayemi Raji ${ }^{2}$ and Kazeem Atanda Sogunle ${ }^{3}$ \\ 1Department of Food Technology, Federal College of Freshwater, Fisheries Technology, \\ New Bussa, Niger State, Nigeria. \\ ${ }^{2}$ Department of Food Science and Technology, College of Agriculture and Veterinary Medicine, \\ Kwara State University, Malete, llorin, Nigeria. \\ ${ }^{3}$ Department of Food Science and Technology, Federal University Dutsinma, Katsina State, Nigeria. \\ ${ }^{*}$ Corresponding author. Email: uchyme@gmail.com
}

Copyright (c) 2019 Ibanga et al. This article remains permanently open access under the terms of the Creative Commons Attribution License 4.0, which permits unrestricted use, distribution, and reproduction in any medium, provided the original work is properly cited.

Received 2nd August, 2019; Accepted 16th September, 2019

\begin{abstract}
Melon (Citrullus vulgaris), groundnut (Arachis hypogea) and shea butter (Vitellaria paradoxa) seeds have been established as major sources of edible oils, but scientific data is scanty on their minerals, heavy metals and antinutrient contents. Manually extracted vegetable oils from melon, groundnut and shea butter were analyzed in triplicates for some minerals (sodium, potassium, magnesium and calcium), heavy metals (copper, iron, lead and zinc) and antinutrients (tannin, saponin, oxalate and gossypol) using Buck Scientific Atomic Absorption Spectrophotometer Model 210 VGP standard procedures. Data were analyzed by ANOVA and results expressed as means and standard deviation accepted at $p \leq 0.05$. Sodium ( 40.50 to $41.10 \mathrm{mg} / 100 \mathrm{~g}$ ), potassium $(702.00$ to $704.36 \mathrm{mg} / 100 \mathrm{~g}$ ); magnesium (3.51 $\mathrm{mg} / 100 \mathrm{~g})$ and calcium $(2.56 \mathrm{mg} / 100 \mathrm{~g})$ were in the oils and they did not differ from one another at $\mathrm{p} \leq 0.05$. The heavy metals in the oils were not significantly different from each other. They ranged from 0.0002 to $0.0004 \mathrm{mg} / \mathrm{kg}$ for lead $(\mathrm{Pb})$; 0.00 to $0.0002 \mathrm{mg} / \mathrm{kg}$ for copper (Cu); 0.0005 to $0.0006 \mathrm{mg} / \mathrm{kg}$ for iron (Fe) and 0.0012 to $0.0015 \mathrm{mg} / \mathrm{kg}$ for zinc (Zn). Antinutrient, tannin from melon differed significantly from those of groundnut and shea butter oils at $p \leq 0.05$. Melon oil had the least saponin $(0.05 \mathrm{mg} / 100 \mathrm{~g})$ and the three oils had the same oxalate content $(0.33 \mathrm{mg} / 100 \mathrm{~g})$. Their gossypol content differed significantly from one another. Shea butter and groundnut oil had the lowest $(0.44 \mu \mathrm{g} / 100 \mathrm{~g})$ and highest $(1.07 \mu \mathrm{g} / 100 \mathrm{~g})$ gossypol contents respectively. The evaluated heavy metals in all the tested oils were lower than the maximum permissible values by FAO/WHO. Further studies on phytates content and other heavy metals such as cadmium, arsenic and mercury are recommended before the oils are certified safe for human consumption.
\end{abstract}

Keywords: Anti-nutrients, heavy metals, minerals, vegetable oils.

\section{INTRODUCTION}

Vegetable oils are oils derived from plant parts like seeds, nuts and fruits. Popular sources include palm fruits, palm kernels, soybeans, olive, sunflower, linseed, coconut, plum and so on. Melon (Citrullus vulgaris), groundnut (Arachis hypogea) and shea butter Vitellaria paradoxa) are oil-seed plants that grow abundantly in several parts of Nigeria. Melons are consumed in soup, roasted, boiled and eaten as snacks or fermented to produce ogiri, a local condiment among the Ibos, in the southeastern part of Nigeria (Barber and Achinewu, 1992). Melon seeds are rich in proteins, fats, essential vitamins and minerals. Despite the importance of melon seeds, most people are discouraged from its cultivation because the post harvest processes are cumbersome, tedious, laborious and time consuming. Also, to meet the demand for its large scale industrial oil production, the traditional hand peeling method of de-shelling melon is slow, time consuming, tedious and inefficient. Some researchers in Nigeria designed and constructed melon shelling machine but their low efficiency and the drudgery of manual 
separation of the shells from the cotyledons, washing and subsequent drying of the cotyledons have been discouraging. Traditionally, melon oil is extracted through the unit operations of sorting, washing, drying, frying, cooling, grinding and mixing with water, oil extraction and filtration.

Groundnut, also known as peanut (Arachis hypogea), is a leguminous food crop that belongs to the family leguminosae. It is an annual crop in the tropical and subtropical regions from which edible oil and protein rich by-products are obtained (Ebuehi et al., 2006). Groundnut oil is extracted from groundnut paste at household and semi- cottage levels using a manual or motor driven screw or hydraulic press to squeeze out the oil water emulsion. The oil is boiled to remove the water and used as cooking oil, for production of margarine, shortening for pastries and bread processing, production of soaps, cosmetics, paints, lubricants, emulsion and for insecticides (Ebuehi et al., 2006). It is also useful as ointment base for fat soluble drugs.

Shea butter plant is of the sapotaceace's family having two main species Vitellaria paradoxa and Vitellaria nilotica (Alander and Anderson, 2004). Shea butter, an edible semi solid fat, is extracted from the plant in areas where it grows. The butter has wide application as a cooking fat, in the chocolate, soap, medicinal, bakery and pharmaceutical industries. Shea butter can be extracted from fried, toasted, boiled and parboiled shea nuts after milling (Ibanga et al., 2015). In Nigeria, application of mechanical devices such as hydraulic or screw press are rarely used for shea butter extraction. Local processors have been reluctant to adopt WATH (2004) mechanized extraction method which has 35 to $40 \%$ efficiency. Shea butter is therefore manually extracted and boiled for clarification.

Minerals are the chemical elements other than carbon, hydrogen, nitrogen and oxygen required by living things in minute quantities for existence and sustenance. Minerals act as catalysts for many biological reactions within the body, including muscle response, the transmission of messages through the various nerves (Reference guide, 2009). Without minerals in the body, vitamins as important as they are can do nothing. Minerals are vital to the overall mental and physical well being of man. They are important constituents of the teeth, bones, muscles, blood, nerve cell and soft tissues. lodine is a mineral most commonly found in iodized salt.

Toxicological and environmental studies have prompted growing interest in determining the heavy metals of water and foods. The qualities of edible oils are evaluated by the determination of trace or heavy metals (Szyczewski, 2016). Trace or heavy metals penetrate into vegetable oils through endogenous and exogenous sources. Some levels of heavy metals like zinc, iron, copper, manganese and lead are known to have adverse effects on oxidative stability of vegetable oils. Trace or heavy metals are metals and metallic compounds that may impart negatively on human health when absorbed or inhaled. They have relatively high densities (more than $5 \mathrm{~g} / \mathrm{cm}^{2}$ ) atomic weight or numbers (Wikipedia 2018). Most heavy metals are toxic when they accumulate in the human body or exceed certain threshold concentration (Hahladakia, 2018). They are contaminants that may occur as residues in foods from the environment, industrial activities or from food processing equipment (Nwokeke et al., 2014). They could be found in water, food, and air, household and cooking wares. They are natural components of the earth crust and are toxic in low concentration. Other examples include mercury, cadmium, arsenic, lead and chromium. As trace elements, some heavy metals like copper, selenium are essential in the maintenance of the human body metabolic activities.

Anti nutrients are natural or synthetic compounds that interfere with the absorption of nutrients in humans. They are compounds that reduce nutrients utilization in food by consumers (Oxford, 2006; Sango et al., 2016; Duru et al., 2018). Phytic acid though could be beneficial, is an antinutrient which often forms insoluble complexes with calcium, zinc, iron and copper. Trypsin inhibitor and lecithin in legumes are other examples of anti nutrients. Food processing methods like fermentation, soaking, cooking and frying decrease anti nutrients and increase nutritive quality and bioavailability of plant foods (Afolabi et al., 2018; Duru et al., 2018).

Local extraction of vegetable oils from the mentioned plants is becoming popular in the areas of production due to population explosion and high cost of industrially extracted vegetable oils. It is therefore important to ascertain their minerals, trace or heavy metals and anti nutrients content and also ensure that the heavy metals are within safety levels for human consumption.

\section{Objective of the study}

Melon (Citrullus vulgaris), groundnut (Arachis hypogea) and shea butter (Vitellaria paradoxa) seeds have been established as major sources of edible oils in Nigeria, but scientific data is scanty on their minerals, heavy metals and anti-nutrient contents. This study was not a comparative study but rather investigated some minerals, heavy metals and anti-nutrients contents of vegetable oils from melon, groundnut and shea butter in New Bussa, Kainji Lake Area of Nigeria and ascertained the safety of the heavy metals for cottage level processing and consumption.

\section{MATERIALS AND METHODS}

\section{The study area}

The work was carried out in New Bussa, Kainji lake Area of Nigeria (Figure 1). The town is the head quarter of Borgu 


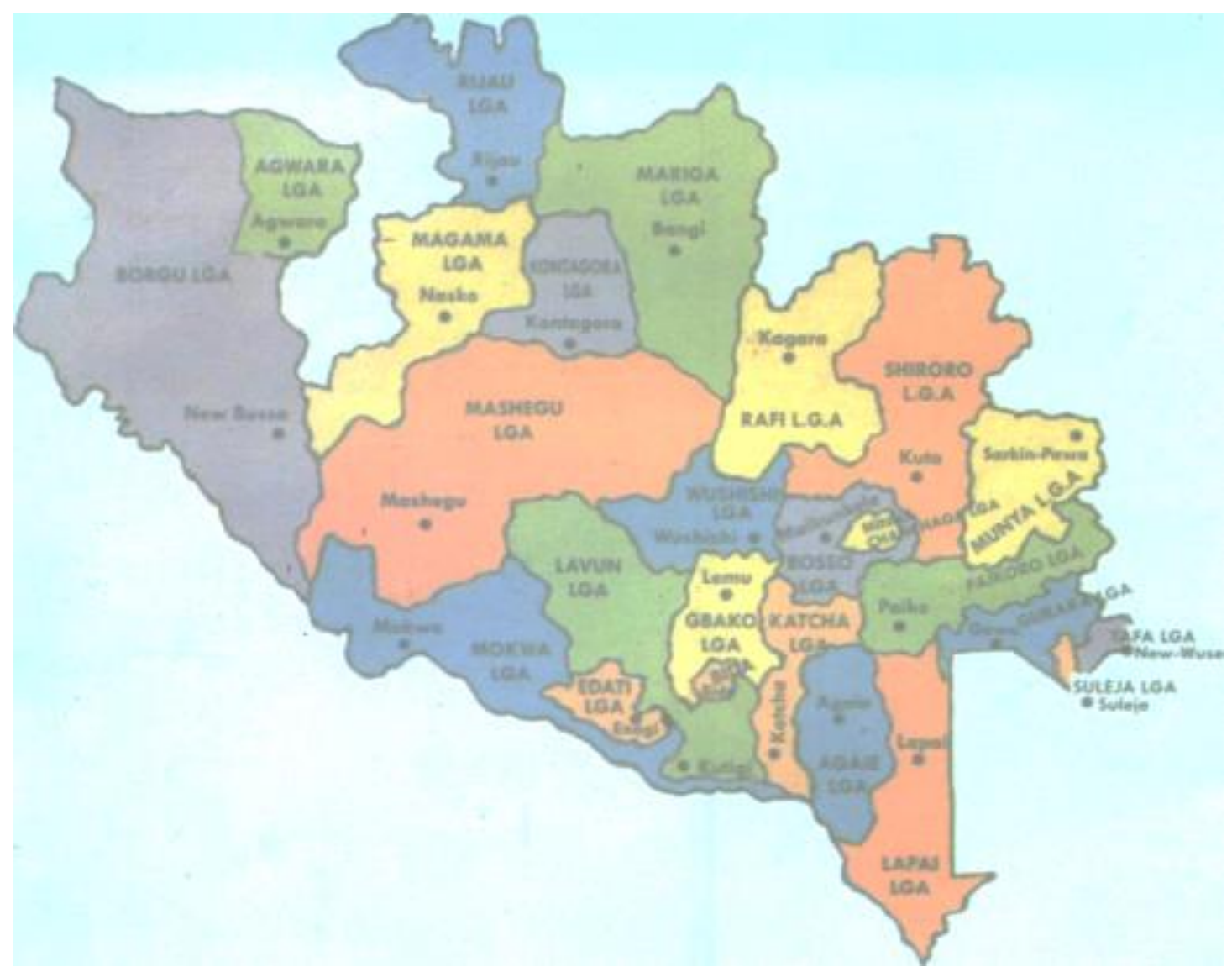

Figure 1. Map of the sampling site - New Bussa in Kainji, Borgu L.G.A, Niger State, Nigeria.

Local Government Area of Niger State, Nigeria. It is situated between latitude $9^{\circ} 50^{\prime}$ to $10^{\circ} 57^{\prime} \mathrm{N}$ and longitude $4^{\circ} 25^{\prime}$ to $4^{\circ} 45^{\prime} \mathrm{E}$ with a surface area of $1,270 \mathrm{~km}^{2}$ and lies at the border of sub-Sudan and Guinea Savanna. The typical vegetation of the area is characterized by tall grasses and land with tall trees forming canopies. The climate is under the control of two main winds the Sudanwest monsoon winds from the Atlantic Ocean and the East trade winds from the South regions thereby giving two distinct seasons (Olokor, 1995). The climate favours the growth of shea butter and other economic and noneconomic trees.

\section{Oils extraction}

De-shelled melon seeds, groundnut and Shea nuts kernels used were bought from the popular Monday Market, New Bussa, Kainji lake area of Nigeria. The oils were extracted in the Food Processing Laboratory of the Department of Food Technology, Federal College of Freshwater Fisheries Technology, New Bussa, using traditional manual methods. The combined flow diagram is as shown in Figure 2. The seeds of each of the plants were separately sorted, washed and sun dried weighed, and toasted mildly $\left(60\right.$ to $65^{\circ} \mathrm{C}$ ) in a big aluminum pot for about 30 minutes. Each was pounded and milled with a locally fabricated grinding machine. The milled slurry was hand mixed gradually with intermittent addition of water in a big bowl. The milled melon and groundnut gradually changed from brownish to dark colour while that of the shea butter changed from chocolate brown to grayish brown and eventually to whitish brown. The oils and fats were separately scooped, boiled and filtered to obtain clear oils. Shea butter oil solidified on cooling.

\section{Determination of minerals and heavy metals}

Buck Scientific Atomic Absorption Spectrophotometer (AAS) model 21 VGP was used, following the methods of AOAC (2000) and Bansal et al. (1993). The oil samples were digested and filtered in Whatman qualitative circles of $125 \mathrm{~mm}$ filter paper. The filtrates were placed in different curvet and labelled accordingly. The specific litch hallow cathode lamps were selected based on the characteristic wavelength of absorption of the different oils. The slit widths for each element were also identified. Each of the samples of interest was set into flame. The metals present in the sample absorbed some of the lights. The computer 


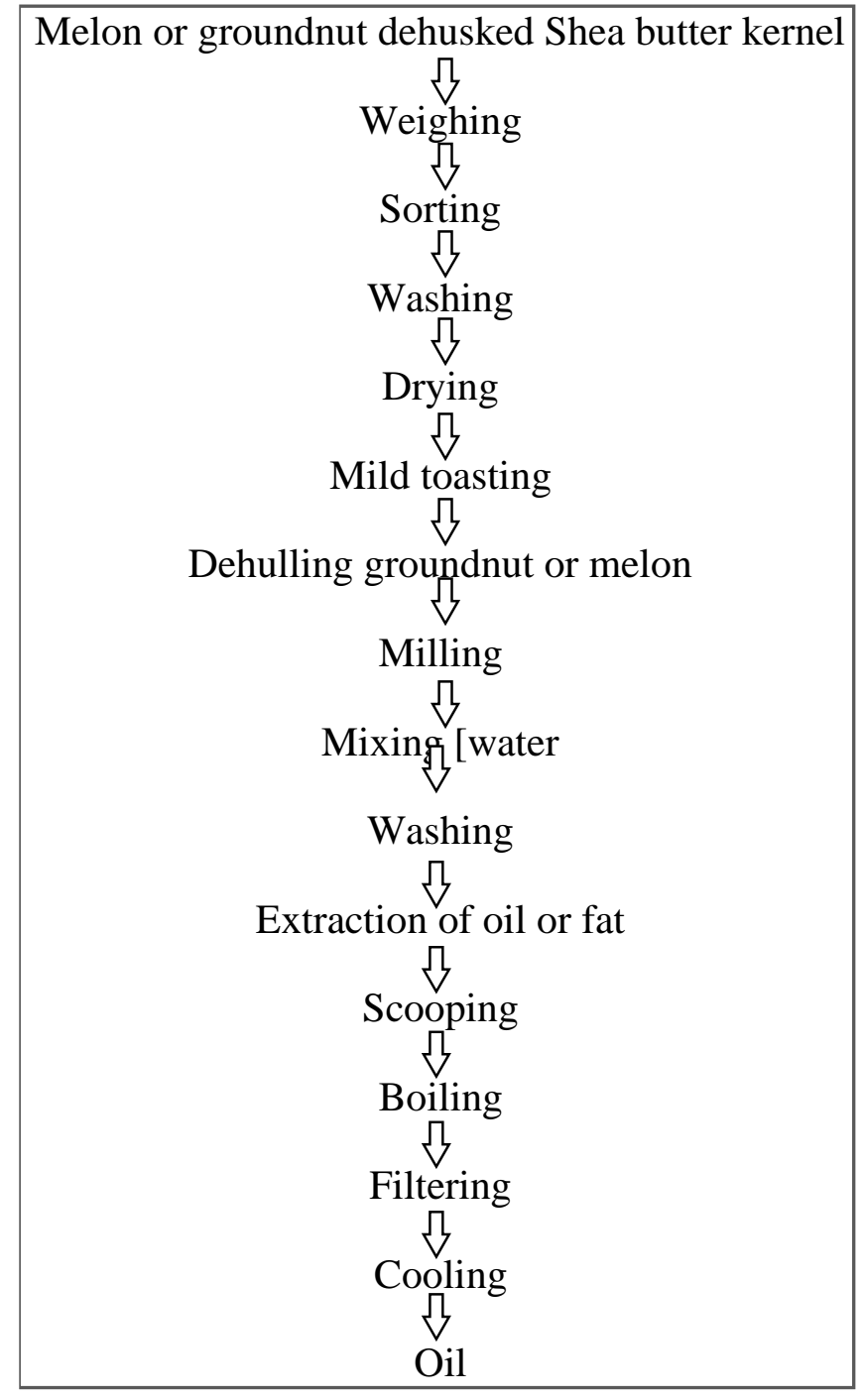

Figure 2. Manual Processing of vegetable oils from melon, groundnut or Shea butter seeds.

data system converted the change in intensity of light into absorbance which was directly proportional to the concentration of the metal present. After calibrating the instrument with standards of known concentration, the minerals were determined from the working curve.

\section{Determination of anti-nutrients}

The anti-nutrients in the oils were determined using the methods of Gilani et al. (2005) with minor modifications. The samples were digested and filtered with Whatman no $1.400 \mathrm{~mm}$ filter paper. The filtrates were placed in different curvets and labeled accordingly. The concentration was determined using AAS at a wavelength of $440 \mathrm{~nm}$. The instruments were adjusted to absorption with aqueous isopropyl alcohol and absorption of the solution was determined. Readings were repeated using freshly distilled aniline. The absorptions of solution were also determined and adjusted using blank reagent and absorption was also adjusted. The concentration of free gossypol (in $\mu \mathrm{g} / 100 \mathrm{~g}$ ) present in solution of the samples was determined using calibration curve. After calibrating the instrument with standards of known concentration, the anti-nutrients were determined from the working curve.

\section{Statistical analysis}

The data were analysed using Statistical Package for Social Science (SPSS) software (version 15.0), ANOVA for means separation and Duncan's multiple range test for comparison of means. Differences were accepted as significant at $p \leq 0.05$.

\section{RESULTS AND DISCUSSION}

As shown in Table 1, the sodium and the potassium contents of the vegetable oils varied from 40.50 to 41.10 $\mathrm{mg} / 100 \mathrm{~g}$ and 702.00 to $704.36 \mathrm{mg} / 100 \mathrm{~g}$ respectively, while the three oils had the same magnesium and calcium contents of $3.51 \mathrm{mg} / 100 \mathrm{~g}$ and $2.56 \mathrm{mg} / 100 \mathrm{~g}$ respectively. There were no significant differences in the mineral contents of the oils. However, groundnut oil had the highest sodium content $(41.10 \mathrm{mg} / 100 \mathrm{~g})$. These results agree with Özcan (2006) that these minerals are among the major minerals in oil seeds. Sodium is a systemic electrolyte that helps to regulate potassium and often obtained in diet from legumes, potato skin, tomatoes, table salt, sea salt, vegetables and milk. Potassium is the predominant mineral in these vegetable oils. This agrees with the reports of many researches that potassium is the most abundant mineral in most agricultural produce (Olaofe and Sanni, 1988; Ibanga, 2015; Enujiugha and Ayodele, 2008). Like sodium, potassium is also regarded as a systemic electrolyte and it is essential in reregulating ATP with sodium. Elemo et al. (2002) reported higher values of calcium, magnesium, sodium and potassium in shea kernels; showing that only a fraction is extracted in the oil as reported by lbanga (2015). Presence of calcium and magnesium is an indication that consumption of these oils is good for bone formation.

Table 2 shows the heavy metal contents of the vegetable oils. The lead, copper, iron and zinc examined ranged from 0.0002 to $0.0004 \mathrm{mg} / \mathrm{kg}, 0.0000$ to $0.0002 \mathrm{mg} / \mathrm{kg}, 0.0005$ to $0.0006 \mathrm{mg} / \mathrm{kg}$ and 0.0012 to $0.0015 \mathrm{mg} / \mathrm{kg}$ respectively. These values are lower than those reported by Farzin et al. (2014) and Zhu et al. (2011) for eight heavy metals such as copper, lead, zinc and iron in nine varieties of vegetable oils in China which posed no risk to human health. The concentration of heavy metals in vegetable oils is criterion for the assessment of their qualities and influence on human health and nutrition. Zinc, a ubiquitous metal in the 
Table 1. Mineral content of manually processed melon, groundnut and shea butter oils.

\begin{tabular}{lccc}
\hline Minerals $(\mathbf{m g} / \mathbf{1 0 0 g})$ & Melon oil & Groundnut oil & Shea butter oil \\
\hline Sodium $(\mathrm{Na})$ & $40.97 \pm 1.42^{\mathrm{a}}$ & $41.10 \pm 1.40^{\mathrm{a}}$ & $40.50 \pm 0.79^{\mathrm{a}}$ \\
Potassium $(\mathrm{K})$ & $702.00 \pm 0.08^{\mathrm{a}}$ & $704.36 \pm 0.11^{\mathrm{a}}$ & $704.36 \pm 0.11^{\mathrm{a}}$ \\
Magnesium $(\mathrm{Mg})$ & $3.51 \pm 0.02^{\mathrm{a}}$ & $3.51 \pm 0.02^{\mathrm{a}}$ & $3.51 \pm 0.02^{\mathrm{a}}$ \\
Calcium $(\mathrm{Ca})$ & $2.56 \pm 0.01^{\mathrm{a}}$ & $2.56 \pm 0.01^{\mathrm{a}}$ & $2.56 \pm 0.01^{\mathrm{a}}$ \\
\hline
\end{tabular}

Values are means of triplicate analysis and standard deviation. Means with different superscripts on a row differed significantly at $p \leq 0.05$.

Table 2. Heavy metals of manually processed melon, groundnut and shea butter oils.

\begin{tabular}{lcccc}
\hline Heavy metals & Melon oil & Groundnut oil & Shea butter oil & FAO/WHO Permissible limit mg/kg \\
\hline Lead $(\mathrm{Pb})$ & $0.0004 \pm 0.00^{\mathrm{ab}}$ & $0.0002 \pm 0.00^{\mathrm{a}}$ & $0.0003 \pm 0.00^{\mathrm{a}}$ & $0.1 \mathrm{mg}$ \\
Copper $(\mathrm{Cu})$ & $0.0002 \pm 0.00^{\mathrm{a}}$ & $0.0000 \pm 0.00^{\mathrm{a}}$ & $0.0001 \pm 0.00^{\mathrm{a}}$ & $0.4 \mathrm{mg}$ \\
Iron $(\mathrm{Fe})$ & $0.0006 \pm 0.04^{\mathrm{ab}}$ & $0.0005 \pm 0.03^{\mathrm{a}}$ & $0.0006 \pm 0.04^{\mathrm{a}}$ & $5 \mathrm{mg}$ \\
Zinc $(\mathrm{Zn})$ & $0.0012 \pm 0.10^{\mathrm{ab}}$ & $0.0015 \pm 0.13^{\mathrm{ab}}$ & $0.0015 \pm 0.13^{\mathrm{ab}}$ & $10 \mathrm{mg}$ \\
\hline
\end{tabular}

Values are means of triplicate analysis and standard deviation. Means with different superscripts on a row differed significantly at $p \leq 0.05$.

Table 3. Antinutrients of manually extracted melon, groundnut and shea butter oils.

\begin{tabular}{lccc}
\hline Antinutrients $(\mathbf{m g} / \mathbf{1 0 0 g})$ & Melon oil & Groundnut oil & Shea butter oil \\
\hline Tannin & $0.15 \pm 0.05^{\mathrm{a}}$ & $1.09 \pm 0.20^{\mathrm{c}}$ & $0.20 \pm 0.09^{\mathrm{b}}$ \\
Saponin & $0.05_{ \pm} 0.02^{\mathrm{a}}$ & $0.12 \pm 0.10^{\mathrm{b}}$ & $0.12_{ \pm} 0.05^{\mathrm{b}}$ \\
Oxalate & $0.33_{ \pm} 0.01^{\mathrm{a}}$ & $0.33 \pm 0.01^{\mathrm{a}}$ & $0.33_{ \pm} 0.01^{\mathrm{a}}$ \\
Gossypol $(\mu \mathrm{g} / 100 \mathrm{~g})$ & $0.71 \pm 0.40^{\mathrm{b}}$ & $1.07 \pm 0.30^{\mathrm{c}}$ & $0.44_{ \pm} 0.02^{\mathrm{a}}$ \\
\hline
\end{tabular}

Values are means of triplicate analysis and standard deviation. Means with different superscripts on a row differed significantly at $p \leq 0.05$.

environment was the highest heavy metal found in the oils under study. The mean values ranged from 0.0012 to $0.0015 \mathrm{mg} / \mathrm{kg}$ and are within the $10 \mathrm{mg} / \mathrm{kg}$ permissible concentration for vegetable oils and margarine (Tashan and Yankov, 2007; FAO/WHO, 2011). According to FAO/WHO (2011), the requirement for zinc for man changes throughout life and it occurs as a natural component in all plant and animal tissues and functions as an integral part of many enzymes. Deficiency of zinc is associated with growth retardation and immunological abnormality in man. The average maximum intake of zinc for an adult is $20 \mathrm{mg} /$ day (FAO/WHO, 2011). Consumers of these vegetable oils need to supplement their daily zinc intake from other sources.

The copper content of the vegetable oils ranged from 0.0000 to $0.0002 \mathrm{mg} / \mathrm{kg}$. These are lower than those of Farzin et al. (2014) and low compared to FAO/WHO maximum permissible standard of $0.4 \mathrm{mg} / \mathrm{kg}$ for crude vegetable oils. Copper intake varies with the type of food consumed, soil condition on which the crop grew and the quality of drinking water. Dietary copper is found in most foods and are known to aid in reducing bad cholesterol and increase good cholesterol levels. Consumers of these oils can supplement their recommended daily copper intake from other sources to meet 0.05 to $0.5 \mathrm{mg} / \mathrm{kg} / \mathrm{body}$ weight.
Traces of lead $(0.0002$ to $0.0004 \mathrm{mg} / \mathrm{kg}$ ) were found in all the vegetable oils and did not differ significantly from one another at $5 \%$ probability level. These values are lower than those of Farzin et al. (2014). Compared to $0.1 \mathrm{mg} / \mathrm{kg}$ $\mathrm{FAO} / \mathrm{WHO}$ standard for lead, these are within the permissible limit for crude vegetable oils.

The iron content of the oils $(0.0005$ to $0.0006 \mathrm{mg} / \mathrm{kg})$ is low compared to $\mathrm{FAO} / \mathrm{WHO} 5 \mathrm{mg} / \mathrm{kg}$ maximum permissible standard for crude vegetable oil and less than that of Farzin et al. (2014). Since iron is an essential trace and heavy metal needed by human for the synthesis of haem protein and many enzymes, other sources of iron should be found for consumers of these vegetable oils to meet FAO/WHO daily intake of $17 \mathrm{mg} /$ day for man and 9 to $12 \mathrm{mg} /$ day for women.

Trace or heavy metals are essential to maintain various biochemical and physiological functions in living organisms when consumed in low concentration and are often contaminants that may occur as residues in foods from food processing equipment or environmental activities. Toasting temperature and duration might have reduced the heavy metals of these vegetable oils during processing. These agree with the findings of Okwunodulu et al. (2018) and Bamidele et al. (2014). The values obtained in this study for heavy metals are within the 
FAO/WHO permissible limits.

Table 3 shows the anti-nutrients in the vegetable oils. The three vegetable oils had the same oxalate content $(0.33 \mathrm{mg} / 100 \mathrm{~g})$ while the concentration of tannin, saponin and gossypol in the oils ranged from 0.15 to $1.09 \mathrm{mg} / 100 \mathrm{~g}$, 0.05 to $0.12 \mathrm{mg} / 100 \mathrm{~g}$ and 0.44 to $1.07 \mu \mathrm{g} / 100 \mathrm{~g}$ respectively and differed significantly from one another at 95\% confidence level. Groundnut oil had the highest tannin and gossypol contents among the oils, but did not differ from shea butter oil in saponin content. Melon oil had the least tannin $(0.15 \mathrm{mg} / 100 \mathrm{~g})$ and saponin $(0.05$ $\mathrm{mg} / 100 \mathrm{~g}$ ) contents while shea butter oil had the least gossypol content $(0.44 \mu \mathrm{g} / 100 \mathrm{~g})$. These anti-nutrients are secondary plant metabolites. The values are low compared to those of edible Garcinia cola (Monago and Akhidue, 2002) and common consumable food in Nigeria such yam, rice, garri, cassava fufu, tapioca and cowpea (Ndie and Okaka, 2018). They should therefore pose no health problem to the consumers.

Oxalates are dianion salts or esters of oxalic acid with a chemical formula of $\mathrm{C}_{2} \mathrm{O}_{4}{ }^{2-}$ (Wikipedia, 2019). They are found in many plants and have the ability to inhibit calcium, potassium and sodium absorption. Betsche and Fretzdorff (2005) reported that oxalate can combine with some ionic metals to form kidney stones. Oxalates occur in many plants where it is synthesized via incomplete oxidation of carbohydrates. Oxalate rich plants consumed by humans include sorrel, spinach, carrot, parsley, beans, tea, cocoa and potatoes. The values obtained for oxalate and tannin contents in this study were in agreement with the findings of Akwaowo et al. (2000). Low values of oxalate observed in this study imply that the oils may not pose any problem when consumed. Although tannin is an anti-nutrient, it has anti-inflammatory properties and known to control gastritis and irritating bowel disorder. It could also contribute to the anti microbial and healing properties of these vegetable oils in traditional medicine.

Gossypol is a natural yellowish phenolic aldehyde that permeates cells and act as an inhibitor for several dehydrogenase enzymes (Wikipedia, 2019). The contents of gossypol in the selected oil samples are within the 1 $\mathrm{mg} / \mathrm{kg}$ acceptable limits. High levels of gossypol have been incriminated in the inhibition of sperm production and thus a male contraceptive (Wang et al., 2009). It is a promising treatment for leukemia and other malignancies (Gadelha et al., 2014).

\section{Conclusion}

Manually extracted vegetable oils from melon, groundnut and shea butter oilseeds in Kainji lake area of Nigeria have varying amounts of minerals, traces of heavy metals and some anti-nutrients. Such minerals include sodium ( $\mathrm{Na})$, potassium $(\mathrm{K})$, magnesium $(\mathrm{Mg})$ and calcium $(\mathrm{Ca})$; heavy metals like lead $(\mathrm{Pb})$, copper $(\mathrm{Cu})$, iron $(\mathrm{Fe})$ and zinc $(\mathrm{Zn})$ and anti-nutrients as tannin, saponin, oxalate and gossypol. All are within consumable limits. Presence of some heavy metals like mercury, arsenic, cadmium and antinutrients such as phytates were not investigated and tannin requires more in-depth studies. These are recommended for further studies to ascertain their presence and levels before manual processing of these oils could be embarked on to reduce over dependency on the expensive imported vegetable oils in the area.

\section{CONFLICT OF INTEREST}

Authors declare that they have no conflict of interest.

\section{REFERENCES}

Afolabi, A. K., Atolagbe, Y. N., \& Kwaya, P. J. (2018). Effect of dehulling and fermentation on anti- nutritional constituents and microbial load of mesquite (Prospsis Africana) seed flours. Proceedings of NIFST 42nd Annual Conference and General Meeting. Pp. 72-73

Akwaowo, E. U., Ndon, B. A., \& Etuk, E. U. (2000). Minerals and antinutrients in fluted pumpkin (Telfairia occidentalis Hook f.). Food chemistry, 70(2), 235-240.

Alander, J., \& Anderson, A. (2004). The shea butter Family - the complete emollient range for Skin care formulations. Cosmetics and toiletries Manufacture Worldwide 2002. Pp. 2832.

AOAC (2000), Official Methods of Analysis. Association of Official Analytical Chemist. 18th edition, Washington DC, USA.

Bamidele, O. P, Adeboye A. S., Oladiran, D. A., \& Ojubanire, B. A. (2014). Effects of processing methods on heavy metals present in fish in Afelele river in Offa, Kwara state. Proceedings of NIFST 38th Annual Conference and General Meetings. Pp. 35-36.

Bansal, U. K., Satija, D. R., \& Ahuja, K. L. (1993). Oil composition of diverse groundnut (Arachis hypogaea L) genotypes in relation to different environments. Journal of the Science of Food and Agriculture, 63(1), 17-19.

Barber, L. I., \& Achinewu, S. C. (1992). Utilization of Melon. Nigeria Food Journal, 10, 129-130.

Betsche, T., \& Fretzdorff, B. (2005). Biodegradation of oxalic acid from spinach using cereal radicles. Journal of Agricultural and Food Chemistry, 53(25), 9751-9758.

Duru, F. C., Ohaegbulam, P. O., Amadi, N. V., Nnaji, K. A., Ojeh, G. O., \& Obioma, F. O. (2018). Effect of different processing treatments on the anti-nutrient qualities of flours of cocoyam. Proceedings of NIFST 42nd Annual Conference and General Meeting. Pp. 97-98.

Ebuehi, O. A. T., Umeh, R. A., \& Oletu, F. U. (2006). Physicochemical and fatty acid composition of two common edible vegetable oils in Nigeria. Nigerian Food Journal, 24(1), 17-24.

Elemo, B. O., Elemo, G. N., Oladimeji, O., \& Komolafe, O. (2002). Studies on the composition of some nutrients and antinutrients of shea nuts (Butyrospermum parkii). Nigerian Food Journal, 20, 6-73.

Enujiugha, V. N., \& Ayodele, O. O. (2008) Evaluation of nutrients and some anti - nutrients in lesser - known, under utilized oilseeds. International Journal of Food Science and Technology, 38(5), 525- 528.

Farzin, L., \& Moassesi, M. E. (2014). Determination of metal 
contents in edible vegetable oils produced in Iran using microwave-assisted acid digestion. Journal of Applied Chemical Research, 8(3), 35-43.

Food and Agriculture Organization of the United Nations/World Health Organization Food Standard Programme Codex Alimentarius Commission (FAO/WHO) 2011.

Gadelha, I. C. N., Fonseca, N. B. S., Oloris, S. C. S., Melo, M. M., \& Soto-Blanco, B. (2014). Gossypol toxicity from cottonseed products. The Scientific World Journal, Article ID 231635, 11 pages.

Gilani, G. S., Cockell, K. A., \& Sepehr, E. (2005). Effects of antinutritional factors on protein digestibility and amino acid availability in foods. Journal of AOAC International, 88(3), 967987.

Hahladakia, J. N. (2018). Standard of the permissible limits of toxin heavy metals and arsenic in fish and sea water and sediments. Retrieved from https://www.researchgate.net/post/Standard_of_the_permissi ble_limits_of_toxic_heavy_metals_and_arsenic_in_fish_and_ sea_water_and_sediment.

Ibanga U. I. (2015). Effects of processing methods on yield, quality and shelf life of shea butter from Vitellaria paradoxa Gartner. Ph.D. Thesis in the Department of Food Technology, University of Ibadan. XXiii +203pp.

Ibanga, U. I., Adegoke, G. O., Akinoso, R., \& Liman, A. (2015). Effect of frying, toasting, boiling and parboiling of sheanuts on fatty acids and phytosterols, profiles of manually extracted shea butter. Elixir Journal of Food Science, 81(2015), 3152531531.

Monago, C. C., \& Akhidue, V. (2002). Estimation of tannin, saponin, oxalate, cyanogenic and cardiac glycosides in Garsinia kola. Journal of Applied Sciences and Environmental Management, 6(1), 22-25.

Ndie, E. C., \& Okaka, J. C. (2018). Risk assessment of antinutrients consupmtion of plant foods of South eastern Nigeria. Journal of Food Science and Nutrition, 1(2), 9-12

Nwokeke, B. C., Adedokun, I. I., Amandikwa, C., \& Mmuoasinam, B. C. (2014). Assessment of heavy metal contents in singed cattle hides (Kponmo) from Owerri, Imo State, Nigeria. Proceedings of NIFST 38th Annual Conference and General Meetings. Pp. 43-44.

Okwunodulu, I. N., Anthony, C. U., \& Okwunodulu, F. U. (2018). Essential heavy metals of food grade plant ashes. Proceedings of NIFST 42nd Annual Conference and General Meeting. Pp. 72-73.
Olaofe, O., \& Sanni, C. O. (1988). Mineral contents of agricultural products. Food Chemistry, 30(1), 73-77.

Olokor, J. O. (1995). Climate of Kainji Lake Basin '1925 - 1994' A report prepared for the Nigeria-German (GTZ). Kainji Lake Fisheries Promotion Project New Bussa. Pp. 99-108.

Oxford Dictionary of biochemical and molecular (2006). Oxford University Press. ISBN 019852171.

Özcan, M. M. (2006). Determination of the mineral compositions of some selected oil-bearing seeds and kernels using Inductively Coupled Plasma Atomic Emission Spectrometry (ICP-AES). Grasas y aceites, 57(2), 211-218.

Reference guide (2009). Reference guide for minerals. An Overview and information on minerals. July 2009.

Sango, C., Marafu, L., \& Zimudzi, C. (2016). Phytochemical, antinutrients and toxicity evaluation of Cleome gynandra and Solanum nigrum: common indigeneous vegetables in Zimbabwe. British Biotechnology Journal, 13(3), 1-11.

Szyczewski, P., Frankowski, M., Zioła-Frankowska, A., Siepak, J., Szyczewski, T., Piotrowski, P. (2016). A comparative study of the content of heavy metals in oils: linseed oil, rapeseed oil and soybean oil in technological production processes. Archives of Environmental Protection, 42(3), 37-40.

Tashan, N., \& Yankov, B. (2007). Research on accumulation of zinc and cadmium in sunflower oil. Journal of Tekirdag Agricultural Faculty, 4(1), 109-112.

Wang, X., Howell, C. P., Chen, F., Yin, J., \& Jiang, Y. (2009). Gossypol-a polyphenolic compound from cotton plant. Advances in Food and Nutrition Research, 58, 215-263.

West Africa Trade Hub [WATH] (2004) The Shea f value chain refining in West Africa Technical Report No. 3. Pp. 40-41.

Wikipedia (2018). Heavy metals. http://en.wikipedia.org/wiki/Heavymetals

Wikipedia (2019). Tannin. Retrieved from https://en.wikipedia.org/wiki/Tannin. Last edited 12th September, 2019.

Zhu, F., Fan, W., Wang, X., Qu, L., \& Yao, S. (2011). Health risk assessment of eight heavy metals in nine varieties of edible vegetable oils consumed in China. Food and Chemical Toxicology, 49(12), 3081-3085. 